\title{
Application of CCME Water Quality Index to Assess the Suitability of Water for Protection of Aquatic Life in Al- Radwaniyah-2 Drainage in Baghdad Region
}

\author{
Adel Mashaan Rabee*, Hasanain Abbood Hassoon and Ahmed Jasim Mohammed \\ Department of Biology, College of Science, University of Baghdad, Baghdad-Iraq. \\ E-Mail: adelmashaan@yahoo.com.
}

\begin{abstract}
The Canadian Council of Ministries of the Environment (CCME) Water quality index used in this study for rating water quality in Al- Radwaniyah-2 drainage indicates that the quality of water in all studied stations is poor. The studied water parameters in it usually deviate from normal levels and the water is not capable to protect or support ample aquatic life. The Results showed that the TDS, Total hardness, Turbidity, Magnesium, Total coliform and Fecal coliform are the main factors responsible for deterioration of the drainage water quality. These parameters need to different procedures to maintain the quality of water in order to protect aquatic life or for any other uses.
\end{abstract}

Keywords: chemical properties, CCME Water quality index, drainage, total coliform.

\section{Introduction}

Assessment of surface water quality can be a complex process undertaking multiple parameters which are capable of causing various stresses on overall water quality [1]. To analyze water quality, different approaches like statistical analyses of individual parameters or multi-stressors water quality indices, etc. have been considered [2]. Various water quality indexes have been developed in the past 40 years [3]. These indices are based on the comparison of the water quality parameters to regulatory standards and give a single value to the water quality of a source $[4,5]$. In general, water quality indices are tools to determine conditions of water quality and, like any other tool require knowledge about principles and basic concepts of water and related issues [6]. The Canadian Council of Ministers of the Environment (CCME) Water Quality Index (WQI) was developed for simplifying the reporting of water quality data [7]. The CCME WQI provides a mathematical framework for assessing ambient water quality conditions relative to water quality objectives [8]. It is flexible with respect to the type and number of water quality variables to be tested, the period of application, and the type of water body (stream, river reach, lake, etc.) tested. The (CCME) Water quality Index (WQI) facilitates to evaluate surface water quality for protection of aquatic life with specific guidelines. Calculations of the index are based on scope (F1); frequency (F2) and the amplitude (F3). Sampling protocol requires at least four parameters, sampled at least four times and no maximum parameters has been set. Water quality guidelines that define physical, chemical or biological characteristics of the water that can not be excluded without causing harmful effects are essential. The resultant index can be referred to a standard table which constitutes numerical values ranging between 0 to 100 with a rating of excellent, good, fare, marginal and poor. Deviating parameters can be monitored depending on the type of aquatic surface quality [7].

The amount and quality of drainage water managed, changes in the rate of flow, physical properties and chemical concentrations need to be determined. Drainage water is no different from any other water supply and is always usable for some purpose within certain quality ranges. This study considered the first attempt in Iraq which describes the application of the CCME Water Quality Index to monitor the changes in water quality at drainage of $\mathrm{Al}$ Radwaniyah-2 in Baghdad area in order to know the suitability of the water properties to protect of aquatic life in this drainage.

\section{Study Area}

AL-Radwaniyah-2 drainage is considered one of the most important projects in Baghdad area, through its contribution to the serve of the agricultural areas in that region and feed 
artificial ponds for breeding fish along waterway. The total length of the Radwaniyah2 drainage reached to 14 Kilometer, while the width varied between 10 to $12 \mathrm{~m}$, depth reached to $2.5 \mathrm{~m}$ and discharge rate close to $5 \mathrm{~m}^{3}$ / Second. Area along waterway known by cultivation of fruits and vegetables and field crops as well as breeding animals of various kinds. Linked to AL-Radwaniyah-2 drainage some small branches and at the end of which the drainage entering main drain called Al-Masab AL-Aam River Fig.(1). Four stations were selected to represent the drainage water quality, first station located at the beginning of the drainage and station 2 located at the end of drainage, while the other two (station 2 and station 3) located in the middle of the drainage.

\section{Methodology}

\section{Sampling and analytical methods}

Samples of water from selected stations were taken twice each season from October 2011 till August 2012. The samples were collected in acid-washed polyethylene sample bottles. After rinsing three times with drainage water, the bottles were immersed at least $30 \mathrm{~cm}$ below the water surface, capped to exclude air, and then returned to the laboratory for analysis. Preservation and transportation of the water samples to the laboratory were as per standard methods [9].Total dissolved solids and $\mathrm{pH}$ were measured in the field with a portable multi meter HANNA Model (HI 9811-5), while all other parameters included total hardness, Dissolved oxygen, $\mathrm{BOD}_{5}, \mathrm{Mg}$, Turbidity, Nitrate and Phosphate were determined in laboratory following the standard protocols [9]. Microbial examinations, which included total coliform (TC) and fecal coliform (FC) conducted according to methods were mentioned in Forbes [10] and Garrity [11].

\section{The CCME WQI}

The CCME WQI model consists of three measures of variance from selected water quality objectives (Scope; Frequency; Amplitude). These three measures of variance combine to produce a value between 0 and 100 that represents the overall water quality. The CCME WQI values are then converted into rankings by using the index categorization schema presented in Table (1).

\section{Calculation of the Index}

After the body of water, the period of time, and the variables and objectives have been defined, each of the three factors that make up the index must be calculated.

The calculation of $F 1$ and $F 2$ is relatively straight forward; $F 3$ requires some additional steps.

F1 (Scope) represents the percentage of variables that do not meet their objectives at least once during the time period under consideration ("failed variables"), relative to the total number of variables measured:

$$
F 1=\left[\frac{\text { number of failed } \text { var iables }}{\text { total number of } \text { var iables }}\right] \times 100
$$




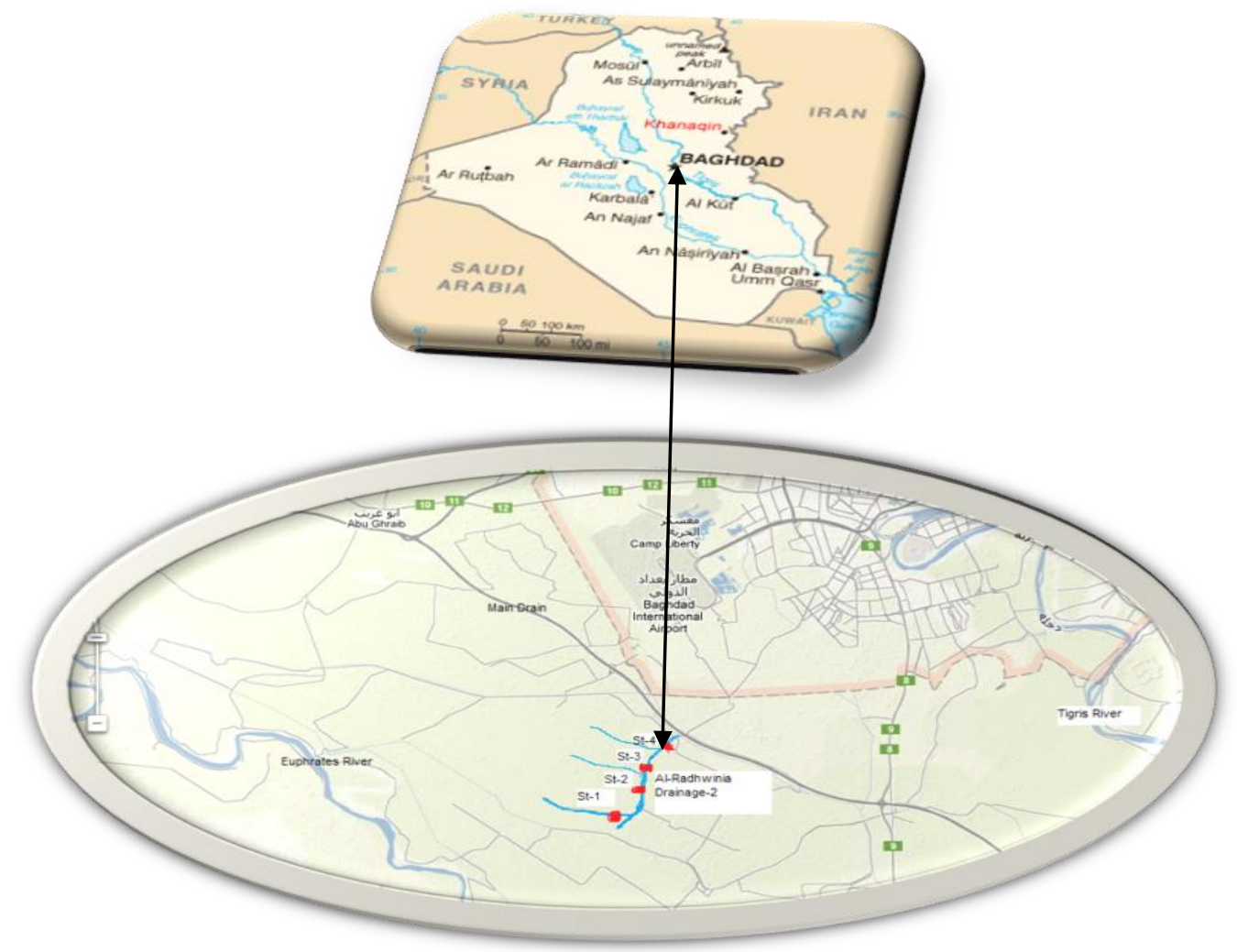

Fig.(1) Map showing current study stations in the Al-Radwaniyah-2 drainage.

Table (1)

CCME WQI categorization schema [CCME2001].

\begin{tabular}{|c||c||l||}
\hline Rank & WQI Value & \multicolumn{1}{c|}{ Description } \\
\hline \hline Excellent & $95-100$ & $\begin{array}{l}\text { Water quality is protected with a virtual absence of threat or } \\
\text { impairment; conditions very close to natural or pristine levels; these } \\
\text { index values can only be obtained if all measurements are within } \\
\text { objectives virtually all of the time. }\end{array}$ \\
\hline \hline Good & $80-94$ & $\begin{array}{l}\text { Water quality is protected with only a minor degree of threat or } \\
\text { impairment; conditions rarely depart from natural or desirable levels. }\end{array}$ \\
\hline \hline Fair & $65-79$ & $\begin{array}{l}\text { Water quality is usually protected but occasionally threatened or } \\
\text { impaired; conditions sometimes depart from natural or desirable } \\
\text { levels. }\end{array}$ \\
\hline \hline Marginal & $45-64$ & $\begin{array}{l}\text { Water quality is frequently threatened or impaired; conditions often } \\
\text { depart from natural or desirable levels. }\end{array}$ \\
\hline \hline Poor & $0-44$ & $\begin{array}{l}\text { Water quality is almost always threatened or impaired; conditions } \\
\text { usually depart from natural or desirable levels. }\end{array}$ \\
\hline
\end{tabular}

F2 (Frequency) represents the percentage of individual tests that do not meet objectives ("failed tests"):

$$
F 2=\left[\frac{\text { number of failed tests }}{\text { total number of tests }}\right] \times 100
$$

F3 (Amplitude) represents the amount by which failed test values do not meet their objectives. F3 is calculated in three steps.

i) The number of times by which an individual concentration is greater than (or less than, when the objective is a minimum) the objective is termed an "excursion" and is expressed as follows. 
When the test value must not exceed the objective:

excurtion $i=\left[\frac{\text { Failed Test Value } i}{\text { Objective } j}\right]-1$

For the cases in which the test value must not fall below the objective:

excurtion $i=\left[\frac{\text { Objective } j}{\text { Failed TestValuei }}\right]-1$

ii) The collective amount by which individual tests are out of compliance is calculated by summing the excursions of individual tests from their objectives and dividing by the total number of tests (both those meeting objectives and those not meeting objectives). This variable, referred to as the normalized sum of excursions, or $n s e$, is calculated as:

$n s e=\left[\frac{\sum_{i=1}^{n} \text { excurtion } i}{\text { Number of tests }}\right]$

iii) $F 3$ is then calculated by an asymptotic function that scales the normalized sum of the excursions from objectives (nse) to yield a range between 0 and 100 .

$F 3=\left[\frac{n s e}{0.01 n s e+0.01}\right]$

Once the factors were obtained, the index itself can be calculated by summing the three factors as if they were vectors. The sum of the squares of each factor is therefore equal to the square of the index. This approach treats the index as a three-dimensional space defined by each factor along one axis. With this model, the index changes in direct proportion to changes in all three factors.

The CCME water quality index is finally calculated as:

$C C M E W Q I=100-\left[\frac{\sqrt{F 1^{2} F 2^{2}+F 3^{2}}}{1.732}\right]$

The factor of 1.732 has been introduced to scale the index from 0 to 100 .

\section{Results and Discussion}

The spatial and temporal variations of monitored parameters in the surface waters of the Al-Radwania-2 drainage are shown in Tables $(2,3,4)$ and $(5)$ respectively.

\section{pH}

The $\mathrm{pH}$ results were very uniform throughout this study, with minor spatial and seasonal differences. The values ranging from 6.5 in October 2011 to 7.8 in February 2012. It is obvious that the $\mathrm{pH}$ was relatively stable among and within stations during the year and seasonal variation of the $\mathrm{pH}$ values did not show significant differences (according to analysis of variance) among study stations. The lowers value of $\mathrm{pH}$ during rainy month (October) may be due to dilution of alkaline substance or atmosphere $\mathrm{CO}_{2}$. The observed $\mathrm{pH}$ values were within the range (6.5-9.0) to permit all natural processes of aquatic life [12].

\section{Total dissolved solids and Total hardness}

Values of TDS recorded concentrations varied between 865 and $1680 \mathrm{mg} / \mathrm{L}$ in all study stations. Most of the results of total dissolved solids have exceeded the permissible limits of $1000 \mathrm{mg} / \mathrm{L}$ recommended by Iraqi and international standard limits. In general, total dissolved solids values $<1000$ are considered fresh water and values > $1000 \mathrm{mg} / \mathrm{l}$ are considered brackish water [13]. No significant difference among stations depending on analysis of variance. During study; total hardness was ranged from $114 \mathrm{CaCO}_{3} / \mathrm{L}$ (in summer) to $1000 \mathrm{mg} \mathrm{CaCO}_{3} / \mathrm{L}$ (in winter). Total hardness considered indicator of hydrogeology and aesthetic quality of water $[14,15]$. In general, high total dissolved solids (TDS) and high total hardness can cause taste problems. The higher TDS of subsurface drainage water may also increase treatment costs due to the increased water hardness. Public values for the protection of aquatic life are concerned with the survival, health and diversity of fish, wildlife and aquatic plants. They may also damage plant and animal health in the long term, or impair the reproductive ability of aquatic species. 


\section{Dissolved oxygen and biological oxygen demand}

Dissolved oxygen refers to the volume of oxygen contained in water. Oxygen enters the water through photosynthesis in aquatic plants or from the transfer of oxygen between the air and water (waves, turbulence, currents, etc). Fast-moving water, lower temperature and lower salinity all result in the availability of more dissolved oxygen [16].

WHO recommended a concentration of dissolved oxygen of $5 \mathrm{mg} / \mathrm{L}$ or above. Dissolved oxygen levels below $5 \mathrm{mg} / \mathrm{L}$ could cause adverse affects to aquatic life [17]. From the results most of the dissolved oxygen concentrations in this study were more than 5 $\mathrm{mg} / \mathrm{l}$.There were significant differences in the oxygen content of water during the course of the six months.

However, the dissolved oxygen concentrations in water samples from the Al-Radwania-2 drainage ranged between 5.1 and $8.4 \mathrm{mg} / \mathrm{L}$. The highest mean concentration of dissolved oxygen was noted in December, probably due to the low water temperature.

Variations of the $\mathrm{BOD}_{5}$ values varied between 1.5 to $4.4 \mathrm{mg} / \mathrm{L}$ throughout the study period. Analysis of variance did not record any significant differences locally and seasonally.

\section{Turbidity and Magnesium}

Turbidity in water is caused by presence of suspended particles such as clay, silt, finely divided organic matter, plankton and other microscopic organisms [18]. Turbidity values in current study varied from 0.1 NTU to 20 NTU. Seasonally, the lowest turbidity values were detected in October, while highest values were recorded in February and April.

Magnesium values varied from 20.4 to $128 \mathrm{mg} / \mathrm{L}$. Magnesium causes hardness in water. Also, higher levels affect human health leading to Encephalitis [13]. Results of Magnesium show that the maximum values exceed the permissible limits according to Iraqi specifications. Analysis of variance does not appear significant differences between the stations.

\section{Nitrate and phosphate}

The two major nutrients in drainage water are nitrogen and Phosphorus. Nitrate is the dominant form of nitrogen in subsurface drainage water. High nitrate concentrations in subsurface drainage can originate from a number of sources: geologic deposits, natural organic matter decomposition and deep percolation of nitrate resulting from fertilizer applications. Nitrate contamination of subsurface drainage water has been documented by Madramootoo et.al. [19]. Agricultural drainage water also contains phosphate in both organic and inorganic forms. Most of the phosphate in surface drainage is in the organic form. Little phosphate has been found in subsurface drainage water because of its strong adsorption in arid zone soils and in humid regions [19]. However, at the watershed scale, controlled drainage has been shown to reduce phosphorus losses [20].

$\mathrm{NO}_{3}^{-}-\mathrm{N}$ values varied from 4.6 to $18 \mathrm{mg} / \mathrm{L}$, while $\mathrm{PO}_{4}{ }^{-3}-\mathrm{P}$ ranging from 2.5 to $108 \mu \mathrm{g} / \mathrm{L}$. Nitrate is one indicator of seasonal variation associated with recharge and solution of fertilizer, contamination from animal or human wastes [14].

No significant differences among studied stations. However, nitrite nitrogen at or below $5 \mathrm{mg} / \mathrm{L}$ and nitrate nitrogen at or below $90 \mathrm{mg} / \mathrm{L}$ would have no adverse effects on most of the warm water fishes [21]. 
Table (2)

Water quality variables and objectives or guidelines used to calculate Water Quality Index in station 1.

\begin{tabular}{|c|c|c|c|c|c|c|c|c|c|c|c|}
\hline 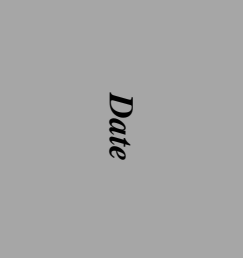 & $\sqrt[3]{2}$ & 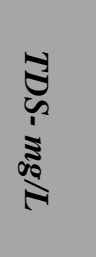 & 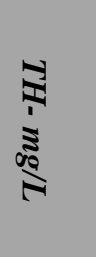 & 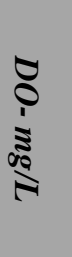 & 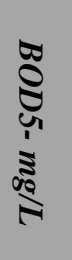 & 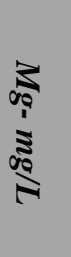 & 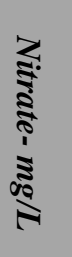 & 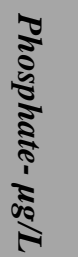 & 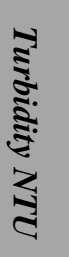 & 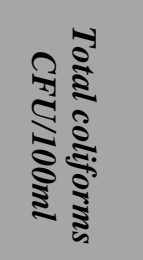 & 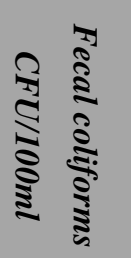 \\
\hline October 2011 & 6.8 & 1200 & 170 & 6.4 & 2.4 & 71 & 9.6 & 101 & 0.1 & $1.5 \times 10^{5}$ & $4 \times 10^{4}$ \\
\hline December 2011 & 6.7 & 1280 & 554 & 5.1 & 2.5 & 70 & 7.9 & 2.5 & 1 & $4.1 \times 10^{4}$ & $2.1 \times 10^{3}$ \\
\hline Febreuary-2012 & 7.6 & 1680 & 1000 & 6.8 & 2.6 & 128 & 18 & 95 & 15 & $2.4 \times 10^{4}$ & None \\
\hline April-2012 & 7.5 & 1150 & 560 & 6.1 & 3.1 & 37 & 8 & 68 & 15 & $8 \times 10^{3}$ & $1 \times 10^{3}$ \\
\hline June-2012 & 7.3 & 980 & 150 & 7.2 & 2 & 37 & 9 & 104 & 10 & $2.3 \times 10^{4}$ & $2 \times 10^{3}$ \\
\hline August -2012 & 7.4 & 998 & 180 & 6.2 & 1.2 & 45 & 13 & 69 & 4 & $2 \times 10^{4}$ & $1 \times 10^{2}$ \\
\hline Objectives & $6.5-9$ & 1000 & 500 & 5 & 2 & 50 & 45 & 100 & 5 & 200 & 200 \\
\hline
\end{tabular}

Bolded values do not meet the objective, objectives have been taken from the Iraqi specifications (26), Egyptian standard limits (24), USEPA (12) and Lumb it al., (8).

Table (3)

Water quality variables and objectives or guidelines used to calculate Water Quality Index in station 2.

\begin{tabular}{|c|c|c|c|c|c|c|c|c|c|c|c|}
\hline శี & $\Xi$ & 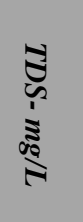 & 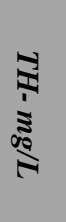 & 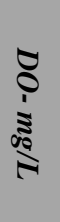 & 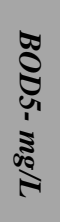 & 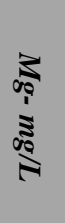 & 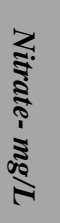 & 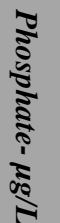 & 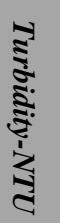 & 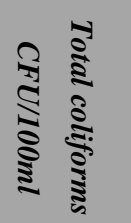 & 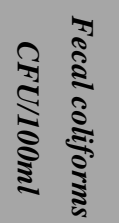 \\
\hline October-2010 & 6.8 & 1230 & 235 & 5.3 & 2.3 & 113 & 11 & 108 & 0.2 & $1.2 \times 10^{5}$ & $6 \times 10^{4}$ \\
\hline December -2011 & 6.6 & 1240 & 508 & 7.2 & 2 & 68 & 8.9 & 4 & 1.5 & $2.9 \times 10^{4}$ & $2 \times 10^{3}$ \\
\hline Febreuary-2012 & 7.8 & 1860 & 992 & 5.8 & 2.9 & 124 & 10 & 14 & 6.5 & $4 \times 10^{3}$ & none \\
\hline April-2012 & 7.2 & 980 & 431 & 5.5 & 1 & 22 & 7.4 & 61 & 20 & $1.2 \times 10^{5}$ & $1.1 \times 10^{4}$ \\
\hline June-2012 & 7.2 & 890 & 141 & 7.8 & 2 & 30 & 11 & 50 & 18 & $2.2 \times 10^{5}$ & $1 \times 10^{4}$ \\
\hline August -2012 & 7.3 & 995 & 200 & 7.1 & 2 & 39 & 12 & 49 & 4 & $1 \times 10^{3}$ & $1 \times 10^{2}$ \\
\hline Objectives & $6.5-9$ & 1000 & 500 & 5 & 2 & 50 & 45 & 100 & 5 & 200 & 200 \\
\hline
\end{tabular}

Bold values do not meet the objective. 
Table (4)

Water quality variables and objectives or guidelines used to calculate Water Quality Index in station 3.

\begin{tabular}{|c|c|c|c|c|c|c|c|c|c|c|c|}
\hline $\begin{array}{l}\text { ๘ } \\
\text { ๙ }\end{array}$ & $\underset{Z}{Z}$ & 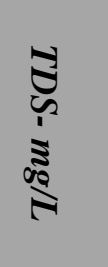 & 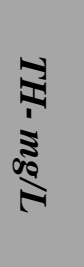 & 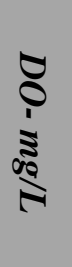 & 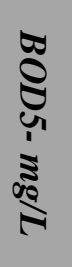 & 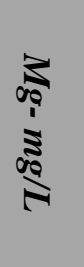 & 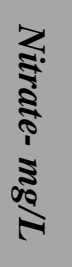 & 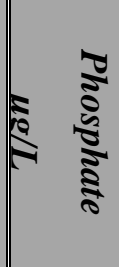 & 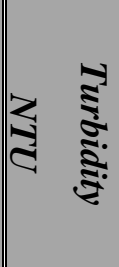 & 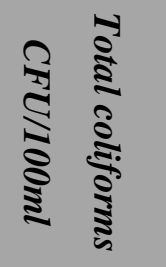 & 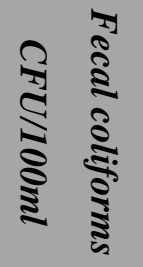 \\
\hline October-2011 & 6.6 & 1040 & 121 & 8 & 6.5 & 37 & 12 & 216 & 0.2 & $1.3 \times 10^{5}$ & $9 \times 10^{4}$ \\
\hline December -2011 & 6.8 & 1160 & 544 & 8.4 & 2 & 68 & 7.5 & ND & 0.9 & $6.9 \times 10^{4}$ & $4 \times 10^{3}$ \\
\hline Febreuary-2012 & 7.7 & 1260 & 992 & 8.1 & 6.1 & 124 & 21 & 40 & 5 & $1 \times 10^{4}$ & none \\
\hline April-2012 & 7.3 & 950 & 432 & 7.7 & 1 & 20 & 4.6 & 43 & 14 & $4 \times 10^{4}$ & $11 \times 10^{3}$ \\
\hline June-2012 & 7.2 & 920 & 114 & 7.9 & 2 & 30 & 9.7 & 56.4 & 15 & $2.3 \times 10^{5}$ & $2 \times 10^{3}$ \\
\hline August -2012 & 7.5 & 980 & 400 & 7.1 & 2 & 49 & 7 & 42 & 10 & 350 & 140 \\
\hline Objectives & $6.5-9$ & 1000 & 500 & 5 & 2 & 50 & 45 & 100 & 5 & 200 & 200 \\
\hline
\end{tabular}

Bolded values do not meet the objective, ND=Not detected.

Table (5)

Water quality variables and objectives or guidelines used to calculate Water Quality Index in station 4.

\begin{tabular}{|c|c|c|c|c|c|c|c|c|c|c|c|}
\hline ఫ) & 3 & 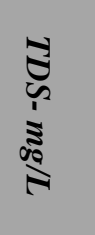 & 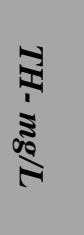 & 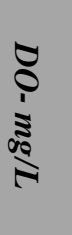 & 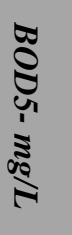 & 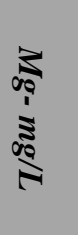 & 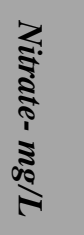 & $\sqrt{\frac{0}{\sqrt[3]{2}}}$ & 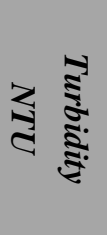 & 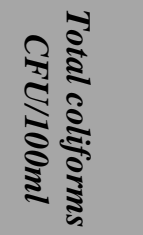 & 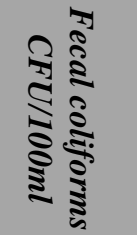 \\
\hline October-2011 & 6.5 & 1050 & 144 & 6 & 4.4 & 59 & 12 & 184 & 0.3 & $1.6 \times 10^{5}$ & $8.8 \times 10^{4}$ \\
\hline December -2011 & 6.8 & 1080 & 605 & 8 & 1.5 & 73 & 6.6 & ND & 1.5 & $1.2 \times 10^{3}$ & $1.2 \times 10^{2}$ \\
\hline Febreuary-2012 & 7.8 & 1160 & 992 & 6.7 & 4.3 & 124 & 19 & 13 & 5 & $2.5 \times 10^{4}$ & None \\
\hline April-2012 & 7.2 & 880 & 400 & 6.1 & 1.5 & 56 & 4.1 & 37 & 20 & $6 \times 10^{4}$ & 1. $\times 10^{3}$ \\
\hline June-2012 & 7.1 & 760 & 224 & 7.1 & 2 & 40 & 24.7 & 41.9 & 13 & $3 \times 10^{5}$ & $1.1 \times 10^{3}$ \\
\hline August -2012 & 7.4 & 960 & 300 & 6.9 & 1.8 & 43 & 20 & 23 & 4 & $2 \times 10^{3}$ & $1 \times 10^{3}$ \\
\hline Objectives & $6.5-9$ & 1000 & 500 & 5 & 2 & 50 & 45 & 100 & 5 & 200 & 200 \\
\hline
\end{tabular}

Bold values do not meet the objective, ND=Not detected. 
In the present study, nitrate values were found below the maximum permissible levels for protection of aquatic life.

Phosphorus in the Radwaniyah-2 drainage also varied to certain extents as it ranged between none detected to $216 \mu \mathrm{g} / \mathrm{L}$.It is regarded to be of great importance in the biological productivity and is of vital concern. Hutchinson [22] states that phosphate content increases as a result of sewage contamination. The considerable variation in phosphate content in the present study is due to sewage contamination. According to ANOVA test found significant differences within months of the study.

\section{Total coliform and Fecal coliform}

The coliform organisms have long been recognized as a suitable microbial indicator of drinking-water quality, largely because they are easy to detect and enumerate in water [23]. Although coliform organisms may not always be directly associated to the presence of fecal contamination, the presence of coliforms in water suggests the potential presence of pathogenic enteric microorganisms such as Salmonella spp., Shigella spp. and Vibrio cholera. Total coliform in this study ranged between 350 to $2.3 \times 10^{5} \mathrm{CFU} / 100 \mathrm{ml}$, while Fecal coliform ranged between zero to $6 \times 10^{4}$ $\mathrm{CFU} / 100 \mathrm{ml}$. The number of bacteria recorded in this study clearly indicates the increasing numbers of these bacteria for the permitted number by Iraqi and international specifications $[12,24]$.

The rise in fecal coliform at all studied stations is most likely caused by a combination of lower flows that concentrate bacteria and management of livestock corrals located upstream of the studied stations. The corrals are located directly on the drain and provide direct and constant access to the water by livestock. Inputs from livestock grazing in and the possibility of septic system contamination are also possibilities.

Analysis of variance shows significant seasonal variations with respect with fecal coliform only.

\section{CCME WQI}

The results of the physico-chemical analysis of water in the study stations are represented in Tables $-2,3,4$ and 5. Total numbers of variables examined were 11 . Total number of individual tests were 264, number of parameters whose values were above objective levels were 8 , and number of tests where objective values reached higher concentrations than the observed values included 97.

Values of CCME WQI calculated in this study was $25,29,30$ and 26 in stations 1,2,3 and 4 respectively and indicates that water quality for protection of aquatic life can be rated as poor (Table (1)). Low values of CCME WQIs in Radwaniyah-2 drainage have been attributed to a high level of TDS, Total hardness, Magnesium, turbidity, total coliform and fecal coliform for all four sampling stations. This clearly indicates that the water must be treated to remove the physical impurities and microbial contaminants. In other studies in Iraq and using the same index showed that the water quality of the Tigris and Euphrates Rivers are fluctuated between poor to marginal categories $[18,25]$. There is a need to reduce soil erosion by watershed management techniques, which will cut down the turbidity and TDS in the waters that threaten the aquatic life.

\section{Conclusions and Recommendations}

1. The Canadian Council of Ministers of the Environment (CCME) Water Quality Index for the Al- Radwaniyah-2 drainage is typically of poor quality. Water quality in the drainage is almost always threatened or impaired; conditions usually depart from natural or desirable levels (Table (1)). The majority of TDS, Magnesium, turbidity, total coliform and fecal coliform exceeded objectives, thus impacting the Water Quality Index.

2. Total coliform and fecal coliform densities were always higher than aquatic life objectives, therefore management decisions should ensure cattle and sheep are excluded direct access to water bodies. This will help to minimize bacterial contamination and nutrient loading to Al- Radwaniyah -2 drainage.

3. Overall, strategies need to be implemented to protect and enhance the water quality and habitat in the Al- Radwaniyah-2 drainage. Natural vegetation slows erosion 
and helps reduce the amount of phosphorus and turbidity inputs to the drainage. Where feasible, "naturalize" drainage systems to reduce streambed and stream bank erosion, and allowing opportunities for nutrients to be assimilated and settled out of the drainages.

\section{References}

[1] Almeida, C. A., Quintar, S., Gonzalez, P. \& Mallea, M. A. "Influence of urbanization and tourist activities on the water quality of the Potrero de los Funes River" J. of Environ. Monitoring and Assess. 133 (1-3): 459-465, 2007.

[2] Venkatesharaju, K., Somashekar, R. K. and Prakash, K. L. "Study of Seasonal and spatial variation in surface water quality of Cauvery River Stretch in Karnataka" J. of Ecology and the Natural Environment 2(1): 1-9, 2010.

[3] House, M. A. "Water quality indices as indicators of ecosystem change" Environmental Monitoring and Assessment 15: 255-263, 1990.

[4] Khan, A. A., Paterson, R, \& Khan, H. "Modification and application of the CCMEWQI for the communication of drinking water quality Data in Newfoundland and Labrador". Presented at 38th Central Symposium of Water Quality Research, Canadian Association on Water Quality (February 10-11, 2003), 867 Lakeshore Road, Burlington, ON, Canada, 2003.

[5] Abbasi, S. A. "Water quality indices, state of the art report" National Institute of Hydrology, Scientific Contribution No. INCOH/SAR-25/2002, Roorkee: INCOH, pp 73, 2002.

[6] Nikbakht, M. "The Effect Assessment of Ahvaz No.1, 2, Water Treatment Plant on Karoon water quality". Thesis (M.Sc), Ahvaz: IA University, 2004.

[7] Canadian Council of Ministers of the Environment (CCME). "Canadian water quality guidelines for the protection of aquatic life Canadian water quality index 1.0 technical report". In Canadian environmental quality guidelines. Winnipeg, Manitoba, 2001.
[8] Lumb. A., Halliwell, D. and Sharma, T. "Application of CCME Water quality index to monitor water quality: A case of the Mackenzie River Basin, Canada" Environmental Monitoring and Assessment, 113: 411-429, 2006.

[9] American Public Health Association (APHA). "Standard Methods for the Examination of Water and Wastewater". $20^{\text {th }}$ edition, 1998.

[10] Forbes, A., Sahm, D. \& Wessfeld, A. "Diagnostic microbiology $\left(12^{\text {th }}\right.$ ed)". Elsevir, Houston, Texas, 2007.

[11] Garrity, G., Brenner, D., Krieg, N. \& Stalely, J. "Bergeys manual of systematic Bacteriology, Second edition" Springer. 2004.

[12] United States Environmental Protection Agency (USEPA). "National Recommended Water Quality Criteria" Office of Water, Office of Science and Technology (4304T), 2006.

[13] Udayalaximi, G., Himabindu, D. \& Ramadass, G. "Geochemical evolution of ground water quality in selected areas of Hyderabad, A. P., India" Ind. J. Sc. Tech. 3(5): 546-553, 2010.

[14] Mishra, B. B., Chaturvedi, G. B. and Tewari, D. D. "Water quality index and suitability of water of Kohargaddi dam at district Balrampur, India" Pollution Res. 27(3): 497-500, 2008.

[15] Pei-Yue, L., Hui, Q. and Jian- Hua, W. "Ground water quality assessment based on improved water quality index in Pengyang county, Ningxia, north west China" E-J. Chem. 7(S1): 209- 216, 2010.

[16] Al-Dhamin, A. S., Mahmood, B. M. and Rabee, A. M. "The effect of Al-ThartharEuphrates canal on the some ecological properties of Euphrates River" Iraqi J. of Science 53(1): 52-61, 2012.

[17] Chang, H. "Spatial and temporal variations of water quality in the river and its tributaries, Seoul, Korea, 1993-2002" Water, Air, and Soil Poll. 161: 267-284, 2005.

[18] Al-Janabi, Z. Z., Al-Kubaisi, A. \& AlObaidy, A. M. "Assessment of Water Quality of Tigris River by using Water Quality Index (CCME WQI)" J. of AlNahrain University. 15 (1):119-126, 2012. 
[19] Madramootoo, C. A., Wiyo, K. A. and Enright, P. "Nutrient loses through the tile drains from two potato fields" Appl. Engineering in Agriculture, 8(5):639-646, 1992.

[20] Evans, R. O., Gilliam, J. W. and Skaggs, R.W. "Controlled drainage management guidelines for improving drainage water quality" Cooperative Extension Service, North Carolina State University Publication No. AG-443: 16pp, 1991.

[21] United States Environmental Protection Agency (USEPA) "Quality Criteria for Water, 1986 (Gold Book)" Washington, DC., Office of Water Regulations and Standards. EPA 440/5-86-001, 1986.

[22] Huthinson, G. E. "A Treat..... Limnology" Vol- I, John Wliey and Sons Inc. New York, pp 1015, 1957.

[23] World Health Organization (WHO). "Guidelines for drinking-water quality. 2. Ed" Geneva. Available at: http://www.who.Int /water_sanitation_health, 1993.

[24] Egyptian Higher Committee of Water (EHCW) "Egyptian Standards for Drinking and Domestic Water According to the Act 27/1978 in Regulating of the Public Water Supplies" Egyptian Governmental Press; Egypt, 1995.

[25] A L- Heety, E. A., Turki, A. M. and $\mathrm{Al}$-Othman, E. "Assessment of the water quality index of Euphrates River between Heet and Ramadi cities, Iraq" International J. of Basic \& Applied Sci. 11 (6): 38-47, 2011.

[26] Drinking- water standard of Iraq IQS: 417. "Central Organization for Quality Control and Standardization" Council of Ministers, Republic of Iraq, 2001.
استعمل دليل المجلس الكندي لنوعية المياه (CCME)

في هذه الدراسة لغرض تقييم مدى ملائمة المياه لحماية الحياة

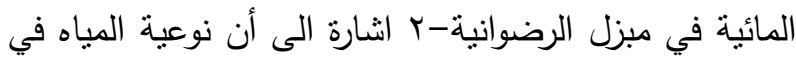
جميع محطات الدراسة كانت رديئة. تتحرف العوامل البيئية المدروسة عادة من المستويات العادية والمياه ليست قادرة على حماية أو دعم حياة مائية وافرة. وأظهرت النتائج أن المواد الصلبة الذائبة الكلية والعسرة الكلية والعكارة والمغنيسيوم ومجموع البكتريا القولونية والبرازية هي العوامل الرئيسية المسؤولة عن تدهور نوعية المياه في مبزل الرضوانية. هذه

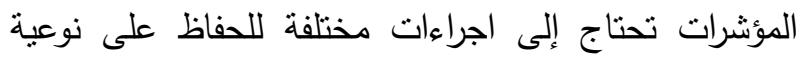
المياه في مبزل الرضوانية من أجل حماية الحياة المائية أو أولئي أية استخدامات أخرى. 